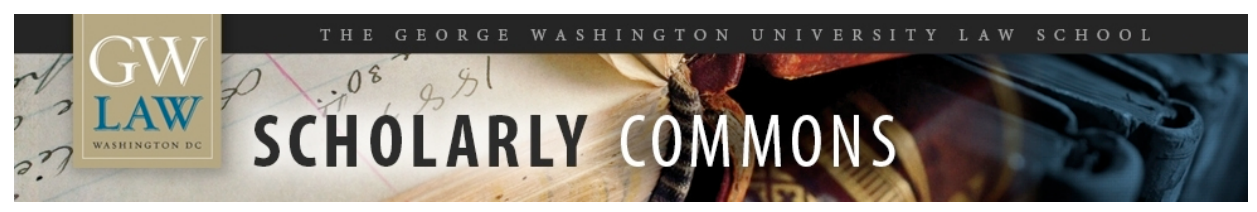

\title{
Campus Discourse and Democracy: Free Speech Principles Provide Sound Guidance Even after the Tumult of 2017
}

\author{
Catherine J. Ross \\ George Washington University Law School, cross@law.gwu.edu
}

Follow this and additional works at: https://scholarship.law.gwu.edu/faculty_publications

Part of the Law Commons

\section{Recommended Citation}

Ross, Catherine J., Campus Discourse and Democracy: Free Speech Principles Provide Sound Guidance Even after the Tumult of 2017 (August 7, 2018). 20 U. Pa. J. Const. L. 787 (2018); GWU Law School Public Law Research Paper No. 2018-34; GWU Legal Studies Research Paper No. 2018-34. Available at SSRN: https://ssrn.com/abstract=3228056

This Article is brought to you for free and open access by the Faculty Scholarship at Scholarly Commons. It has been accepted for inclusion in GW Law Faculty Publications \& Other Works by an authorized administrator of Scholarly Commons. For more information, please contact spagel@law.gwu.edu. 


\title{
GAMPUS DisCOURSE AND DEMOGRAGY: Free SPEEGH PRINGIPLES PROVIDE SOUND GUIDANGE EVEN AFTER THE TUMULT OF 2017
}

\author{
Catherine F. Ross*
}

\begin{abstract}
This Article argues that First Amendment doctrine provides a nuanced and adequate framework for responding to contemporary challenges involving the intersection of free speech, protests, outside agitators, and the risk of violence on college campuses. The Article places contemporary events and concerns in the context of classic free speech doctrine - which binds all public colleges and universities and which many privately-run colleges voluntarily commit to respecting. It also analyzes the import of the unique mission of universities as set out in three seminal university reports on freedom of expression that emphasize intellectual freedom, "full freedom of dissent," and the imperative of protecting viewes that many find deeply offensive.

Using three highly publicized examples of what many regard as the transformation of colleges into political battlegrounds - events in 2017 at the University of California, Berkeley, the Unite the Right rally in Charlottesville, Virginia and Richard Spencer's talk at the University of Florida - this Article provides taxonomies of how outsiders come to speak at campuses, and how they come to be disinvited or prevented from speaking, along with explanations of what the Speech Clause prohibits and permits. The Article provides constitutional and pragmatic guidance respecting best practices for balancing the need to preserve safety in the face of imminent violence (including the presence of weapons) - which requires a real, proximate risk attributable to the speaker before expression can be silenced - against the requirements of the Speech Clause and the sometimes competing imperatives of respecting dignity and equality for all members of the campus community.
\end{abstract}

TABLE OF CONTENTS

I. SETTING THE SCENE.

II. BEYOND HYPERBOLE

III. EMERGING ISSUES: SAFETY VERSUS FREEDOM OF EXPRESSION.....796

IV. STRANGERS AT THE Gate: What Gan Universities Do?

A. Preserve Safety

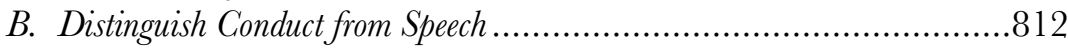

C. Distinguish Initial Invitations from Disinvites................................812

Fred G. Stevenson Research Professor of Law, George Washington University Law School. B.A., Ph.D., J.D., Yale University. I thank the George Washington University and Dean Blake Morant for institutional support, and reference librarian Mary Kate Hunter and my research assistant Abigail Yull, J.D. expected 2018, for their outstanding help. 
D. Promote a Better Understanding of Speech Rights and Responsibilities

\section{SeTting THE SGENE}

The University of Pennsylvania Fournal of Constitutional Law's symposium on campus speech was very timely when we met in February 2017 and, unfortunately, it seems if anything even more timely as this issue goes to press in 2018. The topic could hardly be more urgent. Expressive rights are under the spotlight and, many would say, under siege, on campuses at every educational level from elementary school through university education. Speech rights are also drawing fire and igniting controversy in the country at large.

In the past year, on and adjacent to college and university campuses, outside speakers, some of them intentionally provocative, have inspired raucous demonstrations and counter-demonstrations accompanied by intentional violence and even death. These events have challenged many of our traditional images of the marketplace of ideas, protest, and peaceful assembly. Universities seem either to symbolize the cleavages that divide our society, or to have become the battleground on which those divisions are played out, or both.

More broadly, the first year of the Trump presidency posed unprecedented challenges for free expression. Ramping up both social anxieties and fears for constitutional norms, early in his term President Trump called the press "the enemy of the people," a phrase resonant with Stalinism, Nazism, and other authoritarian forms of government. ${ }^{1}$ In the fall of 2017 he said, "It's frankly disgusting the way the press is able to write whatever they want to write. .. . [P] eople should look into it."2 He has called the NFL players engaged in protests aimed at police brutality and racial injustice "son[s] of ... bitch[es]" and urged private employers to fire them for their views. ${ }^{3}$ These attacks on free speech are so dramatic that one Republican senator-

1 Andrew Higgins, Trump Embraces 'Enemy of the People,' a Phrase with a Fraught History, N.Y. TiMES (Feb. 26, 2017), https://www.nytimes.com/2017/02/26/world/europe/trump-enemy-of-thepeople-stalin.html (discussing the response historians have had to President Trump's use of the phrase "enemy of the people" and the use of the phrase by infamous authoritarian rulers).

2 David Nakamura, Trump Escalates Threats Against Press, Calls Neres Coverage 'Frankly Disgusting,' WASH. POST (Oct. 11, 2017), https://www.washingtonpost.com/politics/trump-escalatesthreats-against-press-calls-news-coverage-frankly-disgusting/2017/10/11/32996dba-ae9c-1 le79e58-e6288544af98_story.html?utm_term=.5efe6f964b14.

3 Sophie Tatum, Trump: NFL Owners Should Fire Players Who Protest the National Anthem, GNN (Sept. 23, 2017, 4:05 PM), http://www.cnn.com/2017/09/22/politics/donald-trump-alabama-nfl/ index.html. 
Ben Sasse of Nebraska - asked the President: "Are you . . . recanting [your] oath ... to preserve, protect, and defend the First Amendment?"4

A 2017 white paper issued by the Newseum lamented that colleges in the United States today "often seem to be the very places in American society where there is the least tolerance for controversial ideas," an image based in large part on "the ad hoc experiences of a few campuses that briefly gained national attention when lecturers were harassed or prevented from speaking by unruly and, occasionally, riotous crowds." 5 These incidents and others - including "mob violence" at the University of California, Berkeley on February 2, 2017 when "two invited speakers were prevented from speaking" in the face of "projected safety concerns that the University failed to control" - led the Senate Judiciary Committee to conduct a hearing on "Free Speech 101: The Assault on the First Amendment on College Campuses," rebroadcast on C-SPAN. ${ }^{6}$ Meanwhile, more than twenty states have adopted new laws purporting to protect free expression on college campuses, while other states passed statutes that would penalize protests, including laws that would allow or require public universities to expel students who participate in violent demonstrations. ${ }^{7}$

4 Press Release, Ben Sasse, U.S. Senator for Neb., Sasse to Trump: Are You Recanting of Your Oath? (Oct. 12, 2017), https://www.sasse.senate.gov/public/index.cfm/press-releases?ID=A903 74B7-44A6-4BC8-82E2-CE01A9418D6E.

5 Jeffrey Herbst, Addressing the Real Crisis of Free Expression on Campus, Newseum 2 (Apr. 25, 2017), http://www.newseuminstitute.org/wp-content/uploads/2017/04/WhitePaper_Herbst_FreeExp ressionOnCampus.pdf. This was written before the events at both Charlottesville and the University of Florida discussed herein.

6 Senator Chuck Grassley, Chairman, Senate Judiciary Comm., Prepared Statement at the Hearing on "Free Speech 101: The Assault on the First Amendment on College Campuses" (June 20, 2017), https://www.judiciary.senate.gov/imo/media/doc/06-20-17\%20Grassley\%20Statement. pdf; Free Speech on College Campuses, C-SPAN (June 20, 2017), https://www.c-span.org/video/ ?430214-1/hearing-focuses-free-speech-college-campuses; see also Stanley Kurtz, Campus ShoutDown Rate Nearly Quadruples, NAT'L REv. (Nov. 2, 2017), http://www.nationalreview.com/corner/ 453357/campus-shout-down-rate-quadruples-free-speech (cataloguing shout-downs of speakers visiting college campuses during 2017, including former FBI director James Comey, the director of the ACLU's Virginia chapter, and others, as well as disruptions of presentations by faculty and administrators).

7 See Bennett Gershman, Republicans Launch the Biggest Protest Crackdown Since the Civil Rights Era, DAILY BEAST (June 20，2017，1:00 AM), https://www.thedailybeast.com/republicans-launch-thebiggest-protest-crackdown-since-the-civil-rights-era (noting these laws may not only violate the First Amendment, but that they are also viewed by some United Nations experts as "incompatible with U.S. obligations under international human rights law"); see also PEN AM., WRONG ANSWER: HOW GOOD FAITH ATtEMPTS TO ADDRESS FreE SPEECH AND ANTI-SEMITISM ON CAMPUS COULD BACKFIRE 8-16 (2017), https://pen.org/wp-content/uploads/2017/11/2017wrong-answer_11.9.pdf (analyzing the model "Campus Free Speech Act" promulgated by the Goldwater Institute and the versions enacted in Arizona and other states, as well as Wisconsin's A.B. 299 - a piece of legislation that has not yet passed the Wisconsin Senate - which provide severe penalties for constitutionally protected speech by students). 
Three events in particular that transpired in 2017 have become shorthand for colleges as free speech and political battlegrounds: the Berkeley confrontation between right-wing and Antifa protesters; ${ }^{8}$ the Charlottesville Unite the Right rally in August 2017 that turned deadly when a white supremacist drove a car into a group of counter-protesters, killing thirty-twoyear-old Heather Heyer and injuring at least thirty-five others; ${ }^{9}$ and the subsequent talk by white nationalist Richard Spencer at the University of Florida on October 19, 2017.10

These dramatic events have understandably captured the popular imagination and drawn ongoing media commentary across the political spectrum. We should not let the focus on dramatic events that bring tensions to the surface mislead us into thinking that all colleges, or all of campus life at some colleges, are dominated by political and cultural conflict captured in divisions over speech. In 2015, PEN America produced a terrific report on the state of speech on American college campuses. It concluded, and I agree, that there is no "pervasive 'crisis' for free speech on campus" but there is much cause for concern if current trends continue. ${ }^{11}$ Most of the nation's 7236 institutions of higher learning ${ }^{12}$ - from community colleges to the most elite research universities - have not experienced dramatic shutdowns of scheduled speakers or violent protests.

I want to use these pages to step back from the seeming precipice by placing the contemporary anxieties and controversies surrounding provocative outsiders invading the campus gates (whether as speakers or demonstrators) within the broader context of history and First Amendment doctrine. I'll consider in turn: parallel events nearly fifty years ago that led universities to explicate their unique role and foundational principles; the emerging challenge of preserving safety and freedom of expression on college campuses; and what First Amendment doctrine permits colleges to do in response to perceived threats to physical safety.

8 Kyle Swenson, Black-Clad Antifa Members Attack Peaceful Right-Wing Demonstrators in Berkeley, WASH. POST (Aug. 28, 2017), https://www.washingtonpost.com/news/morning-mix/wp/2017/08/28/ black-clad-antifa-attack-right-wing-demonstrators-in-berkeley/?utm_term=.aa058d3881d8.

$9 \quad$ Richard Fausset \& Alan Feuer, Far-Right Groups Surge into National View in Charlottesville, N.Y. Times (Aug. 13, 2017), https://www.nytimes.com/2017/08/13/us/far-right-groups-blaze-into-nationalview-in-charlottesville.html.

10 Eric Levenson, Protestors Heckle Richard Spencer at Univ. of Florida Talk, CNN (Oct. 19, 2017, 9:00 PM), https://www.cnn.com/2017/10/19/us/university-florida-richard-spencer-speech/index.html.

11 PeN Am., ANd Gampus For All: Diversity, InClusion, and FreEdom of SPEech at U.S. UNIVERSITIES 64 (2016), https://pen.org/wp-content/uploads/2017/06/PEN_campus_report_ 06.15.2017.pdf.

12 NAT'L CTR. FOR EDUC. STATISTICS, Number of Educational Institutions by Level and Control of Institution: Selected Years, 1980-81 Through 2013-14, in DigEsT OF Education STATISTICS tbl 105.50 (2016), https://nces.ed.gov/programs/digest/d15/tables/dt15_105.50.asp. 


\section{BEYOND HYPERBOLE}

Most college students in the U.S. attend public colleges run by the government ${ }^{13}$ - the First Amendment is mandatory on those campuses. In addition, a majority - probably the vast majority - of private, non-profit colleges have voluntarily undertaken to respect freedom of expression, beyond what we usually capture in the term "academic freedom."14 We evaluate whether they are living up to that commitment through the lens of First Amendment doctrine.

A few foundational principles governing freedom of expression (presumably well-known to most readers of this fournal) bear directly on any discussion of how colleges should handle disputes over controversial speech. First, the First Amendment protects the thought we hate; it is designed to shelter the dissident, no matter how offensive or foolish. ${ }^{15}$ Second, the censorship forbidden by the Speech Clause includes both prior restraint and punishment of protected speech after the fact. ${ }^{16}$ Third, the best response to noxious speech is more and better speech. ${ }^{17}$ Fourth, and of enormous significance for the discussion that follows, the principle of the so-called but misnamed "heckler's veto." That doctrine states the constitutional principle that the state must protect speakers from hecklers who would veto a speaker and shut the speaker down. ${ }^{18}$ Under the First Amendment the authorities must protect the speaker from hecklers and preserve the right to

13 Id.

14 Catherine J. Ross, Assaultive Words and Constitutional Norms, 66 J. LEGAL EDUC. 739, 739 (2017).

15 See, e.g., Abrams v. United States, 250 U.S. 616, 630 (1919) (Holmes, J., dissenting) (freedom of expression protects "opinions that we loathe and believe to be fraught with death"); see also Cohen v. California, 403 U.S. 15, 26 (1971) ("[o]ne of the prerogatives of American citizenship is the right to criticize public men and measures - and that means not only informed and responsible criticism but the freedom to speak foolishly and without moderation." (alternation in original) (internal quotation marks omitted) (quoting Baumgartner v. United States, 322 U.S. 665, 673-74 (1944))).

16 See New York Times Co. v. United States, 403 U.S. 713, 714 (1971) ("Any system of prior restraints of expression comes to this Court bearing a heavy presumption against its constitutional validity." (internal quotation marks omitted) (quoting Bantam Books, Inc. v. Sullivan, 372 U.S. 58, 70 (1963))); Freedman v. Maryland, 380 U.S. 51, 60 (1965) (holding that a state censorship system for screening out obscene movies that "fails to provide adequate safeguards against undue inhibition of protected expression" constitutes an invalid previous constraint); see also Texas v. Johnson, 491 U.S. 397, 399 (1989) (holding that a criminal conviction for expressive conduct protected by the First Amendment violates the Constitution); Cohen, 403 U.S. at 26 (finding that a state may not criminalize protected expression).

17 See, e.g., Abrams, 250 U.S. at 630 (Holmes, J., dissenting) (explaining that "the ultimate good desired is better reached by free trade in ideas - that the best test of truth is the power of the thought to get itself accepted in the competition of the market").

18 See Hill v. Colorado, 530 U.S. 703, 715-18 (2000) (holding that while "[t]he right to free speech, of course, includes the right to attempt to persuade others to change their views, and may not be curtailed simply because the speaker's message may be offensive to his audience," this right is not absolute and must be balanced against the right of unwilling listeners to be "let alone" (citing Frisby v. Schultz, 487 U.S. 474, 487 (1988))). 
speak by, if necessary, removing the hecklers. ${ }^{19}$ Sometimes the heckler only uses words - but so loud the speaker is drowned out, and sometimes hecklers also rely on illegal conduct including violence or threats of violence. ${ }^{20}$

But let's move briefly beyond the First Amendment to the unique role of institutions of higher learning in promoting the marketplace of ideas ensconced in First Amendment doctrine. Private universities have produced three seminal reports on the role of free expression in the academy over the last fifty years. ${ }^{21}$ Together, they explain why free expression matters so much in higher education. They set out some of the principles that should inform any discussion of free expression on college campuses. I focus initially on events at Yale.

In 1974, hecklers prevented a scheduled debate at Yale featuring William Shockley - a Nobel prize-winning physicist who went outside his expertise to promote his view that blacks were genetically inferior to whites. ${ }^{22}$ The events surrounding his aborted talk look a lot like recent incidents involving cancellations of talks by Charles Murray and, like the Murray events, they received national attention. Murray's recent campus appearances have elicited ferocious objections because of the views of genetic differences between racial groups expressed in his most famous work, The Bell

19 See McIntosh v. Ark. Republican Party, 766 F.2d 337, 341 (8th Cir. 1985) (holding that the plaintiff had no constitutionally protected right to assert his presence and his agenda during a private luncheon supporting the governor's re-election bid "under the guise of exercising general rights of free speech").

20 See Cox v. Louisiana, 379 U.S. 536, 552 (1965) ("Speech is often provocative and challenging. It may strike at prejudices and preconceptions and have profound unsettling effects as it presses for acceptance of an idea. That is why freedom of speech ... is ... protected against censorship or punishment. ..."); Terminiello v. Chicago, 337 U.S. 1, 3 (1949) (reversing plaintiff's conviction under a state statute prohibiting "misbehavior which violates the public peace and decorum" after a large crowd gathered outside of the plaintiff's public speech, causing several disturbances (internal quotation marks omitted) (citing the trial court's jury instruction)); see also McCullen v. Coakley, 134 S. Ct. 2518, 2531-32 (2014) (noting that speech may not be regulated because of its impact on the audience or listeners' negative reactions to the speech, but large crowds can "compromise public safety").

21 G. VANN WOODWARD ET AL., REPORT OF THE COMMITTEE ON FREEDOM OF EXPRESSION AT YALE $\S \S 1,2$ (1974) [hereinafter WOODWARD REPORT], https://yalecollege.yale.edu/deansoffice/reports/report-committee-freedom-expression-yale; Kalven Committee, Report on the University's Role in Political and Social Action, U. OF CHICAGO (Nov. 11, 1967) [hereinafter Kalven Report], https://provost.uchicago.edu/sites/default/files/documents/reports/KalvenRprt.pdf; Geoffrey R. Stone et al., Free Speech on Campus: A Report From the University Faculty Committee, U. OF CHI. L. SCH. (Jan. 6, 2015) [hereinafter Stone Report], https://www.law.uchicago.edu/news/free-speechcampus-report-university-faculty-committee. For a discussion of the Kalven and Stone reports, see Ross, supra note 14, at 745-46 (discussing the underlying First Amendment principle embedded in the Kalven and Stone reports that the best response to bad speech is more and better speech).

22 Tale Protestors Silence Shockley, N.Y. TIMES, Apr. 16, 1974, at 77. 
Curve, published in 1994, even though his lectures today concern other matters, like the implosion of the middle class. ${ }^{23}$

In response to the aborted Shockley event, Yale undertook an inquiry into the condition of free expression on campus, resulting in a report authored by C. Vann Woodward, a renowned historian of the American South and thus thoroughly versed in the importance of expressive rights to social and political progress. Woodward emphasized several other important values but insisted that free speech trumps all other priorities, including most centrally the "important" value of "a decent respect for others." 24 The tension between these sets of values is again at issue on campuses today.

The Woodward Report rests on the premise that intellectual freedom and "growth and discovery" require "the right to think the unthinkable, discuss the unmentionable, and challenge the unchallengeable."25 That belief, the committee wrote, is "embodied in American constitutional doctrine but not widely shared outside the academic world." 26

Universities are different from other institutions because their "central purpose" is unfettered intellectual inquiry: the "discovery and dissemination of basic knowledge." To that end, the report posited in words that still resonate today: the university can never let other "important values," including "friendship, solidarity, harmony, civility, or mutual respect," take precedence over the free flow of ideas. ${ }^{27}$

The report highlighted the University's commitment to protecting speakers whose views contradict majority opinion. When tough choices need to be made, it "may sometimes be necessary in a university for civility and mutual respect to be superseded by the need to guarantee free expression."28 Joining a university community constitutes an undertaking to live by that principle.

23 See generally Peter Beinart, A Violent Attack on Free Speech at Middlebury, ATLANTiC (Mar. 6, 2017), https://www.theatlantic.com/politics/archive/2017/03/middlebury-free-speech-violence/518667/ (imploring liberals to respect and protect the rights of ideological minorities to express unpopular and even reprehensible ideas to prevent the voice of the progressives from vetoing the voice of the minority); Nathan J. Robinson, Why is Charles Murray Odious?, CuRRENT AFF. (July 17, 2017), https://www.currentaffairs.org/2017/07/why-is-charles-murray-odious (arguing that while it may not be appropriate to restrict unpopular or suspect speech in principle, the ideas espoused by Charles Murray reasonably give rise to a concern that allowing him a platform legitimates his racist views); Martin Slagter, Protestors Disrupt Charles Murray Speech in Tense University of Michigan Visit, MLive (Oct. 12, 2017), http://www.mlive.com/news/ann-arbor/index.ssf/2017/10/university_ of_michigan_protest_2.html (describing the student response to a scheduled speech by Charles Murray on the University of Michigan campus).

24 WOODWARD REPORT, supra note $21, \S 1$.

25 Id.

26 Id.

$27 \quad I d$.

28 Id. 
These general principles appear as well in the two other foundational reports - both issued by the University of Chicago, and both written by leading First Amendment scholars: Harry Kalven and Geoffrey Stone. Kalven's report was issued in 1967-like today, a time of political and cultural cleavage. ${ }^{29}$ Anticipating Woodward, Kalven emphasized that the "distinctive mission" of the University - serious intellectual inquiry - requires "the widest diversity of views." 30 The University (like a democracy), the Kalven Report emphasized, thrives on the "full freedom of dissent." 31 Nearly fifty years later, Stone's report underscored: " $[1] \mathrm{t}$ is not the proper role of the University to attempt to shield individuals from ideas and opinions they find unwelcome, disagreeable, or even deeply offensive." 32 Rather, individuals on the campus must assess one another's expression and, the Stone Report urged, respond where needed, "not by seeking to suppress speech, but by openly and vigorously contesting the ideas that they oppose." 33 In other words, engaging.

This is classic free speech doctrine, without exception or gloss, applied to the college campus: the best response to bad speech is more and better speech. And it provides the needed context for understanding a muchdiscussed letter a dean at Chicago wrote to admitted undergraduates who were about to matriculate in 2016: it warned that upon enrolling they should anticipate "challenge" and "even . . . discomfort."

Sadly, not all university leaders agree. Most dramatically, perhaps, in 2016 Morton Schapiro, the President of Northwestern University, defending "safe spaces," dismissed First Amendment concerns as those of "lunatics" and "idiots." 35 Such objections must not be allowed to gain traction. The jurisprudence is clear. First Amendment doctrine has never entertained the prospect that other worthy values, including equality and dignity, could outweigh freedom of expression. ${ }^{36}$

In short, as the seminal reports underscore, free expression in college is not just a matter of law or luxury. The academy's central mission is to

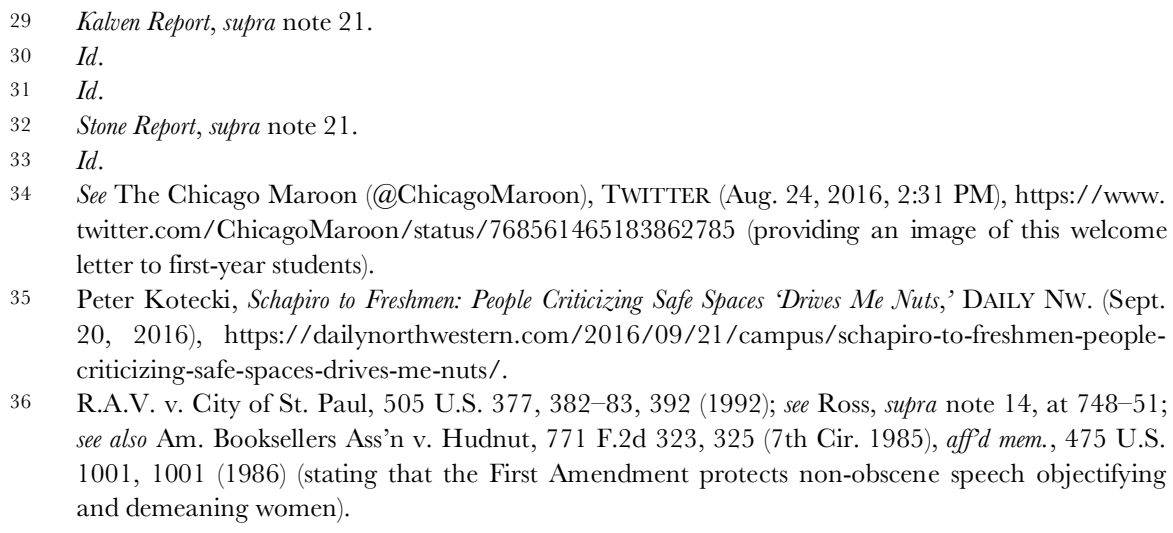


promote critical thinking in teaching, learning and research: grappling with unsettling views and information, suspending beliefs, challenging long-held truths, and seeking to refine and articulate new, more complex understandings. This requires students (and faculty) to challenge and be challenged. As Harry Kalven advised in 1967, and one cannot say it too often: "a good university, like Socrates, will be upsetting." 37

That does not mean that anything goes on a college campus. The First Amendment distinguishes between expression and conduct, though that line is often murky, and colleges too can and should distinguish between expression and behavior. Conduct that violates constitutionally permissible rules and statutes may always be punished without violating a speaker's rights. Some, perhaps many, campus incidents involve a mix of conduct and expression. ${ }^{38}$

In the face of cancelled events and shout downs at campuses around the country, the University of Chicago once again took a leading role. In the spring of 2017 it reiterated its commitment to free expression by focusing on what to do about members of the university community and outsiders who prevent speakers from talking. ${ }^{39}$ Chicago's report on Discipline for Disruptive Conduct warns students that they will be disciplined if they block or suppress "the free-speech rights of others." 40 Protesters are, the document says, "fully within their free-speech rights to counter and object to speech," but while "[d]isruptive conduct may itself be a form of speech" it is not protected speech - like other acts of civil disobedience, it is subject to penalty. ${ }^{41}$ Students may be disciplined; outsiders may be barred from campus. ${ }^{42}$ As is so often the case, the devil will be in the details - especially in making clear what conduct crosses the line to disruption that can be punished.

The University of Chicago also indicated this year that all speakers are not equal in demanding a campus podium. The primary speech the University should facilitate, the 2017 statement indicated, is that "determined by the faculty, other scholars and students" at the University subject to

37 Kalven Report, supra note 21 , at 1.

38 The nuances and difficulties of distinguishing the non-expressive parts of conduct from expressive acts are beyond the scope of this Article.

39 See generally Univ. Of CHI. COMm. On Univ. Discipline FOR DisRuPTIVE CONDUCT, ReviSED FINAL REPORT OF THE COMMITTEE ON UNIVERSITY DISCIPLINE FOR DISRUPTIVE CONDUCT (2017) [hereinafter U. CHICAGO REvisED FINAL REPORT], https://provost.uchicago.edu/sites/ default/files/DCGRevisedFinal\%20\%286-2-2017\%29.pdf (embodying the final report of the committee asked by the Provost of the University to "review and make recommendations about procedures for student disciplinary matters involving disruptive conduct including interference with freedom of inquiry or debate").

$40 \quad$ Id. at 2

$41 \quad I d$.

$42 \quad$ Id. at $4,12-13$. 
"reasonable rules" that will promote an "inclusive climate" that allows the "speech to thrive." 43 These guidelines will have to be fleshed out carefully, but provide a potential model as other colleges and communities consider how to respond to recent events.

\section{EMERGING ISSUES: SAFETY VERSUS FREEDOM OF EXPRESSION}

For several decades, we have had the luxury of ignoring the prospect of violence at protests - at least on campus. ${ }^{4}$ But the threat of violence, especially where counter-protesters show up, is nothing new, and First Amendment jurisprudence offers clear guidance about how to handle the delicate balance between freedom of expression and preservation of public safety.

If the problem is not unfamiliar in the First Amendment landscape, its appearance at or near college campuses may be. ${ }^{45}$ Protests and counterprotests are long, expressive traditions. The overarching principle is that any regulations respecting demonstrations must be content-neutral and administered without regard to the viewpoint the protesters are expressing. ${ }^{46}$ Where the official in charge of permitting lacks discretion to deny a permit based on what the demonstrators want to say, the regulatory scheme is likely to be upheld. However, as the Supreme Court has noted, "even contentneutral time, place, and manner restrictions can be applied in such a manner as to stifle free expression.... there is a risk that he will favor or disfavor speech based on its content"- precisely the allegation that has succeeded

$3 \quad I d$. at 2

44 Some fifty years ago, there were widespread concerns about violence and unrest on college campuses in a time when the nation faced "divisions as deep as any since the Civil War." U.S. GOV'T Printing OfFice, The Report of the President's Commission on Campus UnRest 1 (1970). A national commission recommended that students who resort to violence must be identified, removed from campus and prosecuted. Id. at 7. It also condemned as "criminals" the "Police and National Guardsmen who needlessly shoot or assault students" as happened at Kent State and Jackson State. Id. at 2; Kent State Shooting Divided Campus and Country, NPR: TALK OF NATION (May 3, 2010, 1:00 PM), https:www.npr.org/templates/story/storyphp?/StoryId= 126480349 (summarizing events of May 1970, in which the Ohio National Guard shot and killed four people and wounded nine others at Kent State during an anti-war protest, and ten days later Mississippi police shot and killed two students, wounding twelve others at Jackson State - a historically black college — when law enforcement officials fired over 200 rounds of bullets into a women's dormitory; both shootings occurred without provocation).

45 During the 1960 s and 1970 s, violence occurred or was feared on or near campuses during protests, but the incidents involved conflicts with law enforcement agencies, including the national guard, rather than conflicts between groups of demonstrators.

46 See Thomas v. Chi. Park Dist., 534 U.S. 316, 323 (2002) (noting that time, place, and manner regulations administered in a viewpoint-neutral manner safeguard "the good order upon which [civil liberties] ultimately depend" (alteration in original) (citing Cox v. New Hampshire, 312 U.S. 569, $574(1941)))$. 
when those who wish to march on or near a campus, or whose invitations to speak on campus have been rescinded turn to the courts for relief. ${ }^{47}$

As far back as 1934, in the early days of the First Amendment's doctrinal development, the ACLU struggled with how to balance freedom of speech with public safety in considering whether to support the right of Nazis to march in the United States at a time when Nazis were far more than a fringe group internationally. Their rise in Germany had begun with marches, brawls, and mob power. The ACLU drew the line at permitting Nazis to demonstrate in the United State while "drilling with arms." 48 In Charlottesville, many of the white nationalists were openly carrying guns - and state law protected their right to do so. ${ }^{49}$ This raises the safety stakes significantly. ${ }^{50}$

Leaving guns and open carry laws aside for the moment, First Amendment doctrine has grappled with the speech/safety dichotomy at least since the heyday of the civil rights movement. As Justice Goldberg put it in Cox v. Louisiana, free speech and the right of assembly are subject to content-

47 Id. at 323 (stating that circumscribed discretion and effective judicial review are needed). This was the fatal error when the City of Charlottesville revoked a permit it had given to Jason Kessler, an organizer of the Charlottesville demonstration, at "the eleventh hour," and moved his group to a less central and less desirable location a mile away, while leaving in place the permit the City had granted to counter-protesters. See Kessler v. City of Charlottesville, No. 3:17CV00056, 2017 U.S. Dist. LEXIS 128330, at *3, *7-9 (W.D. Va. Aug. 11, 2017) (granting a preliminary injunction enjoining revocation of the original permit because the city's "safety concerns" were speculative, and the counter-protesters received preferential treatment); see also Padgett v. Auburn Univ., No. 3:17-GV-231-WKW, 2017 U.S. Dist. LEXIS 74076, at*2-5 (M.D. Ala. Apr. 18, 2017) (granting a preliminary injunction ordering the university to rent a room to plaintiff to be used for a talk by Richard Spencer and others, absent evidence that Spencer "advocates violence" or will produce "imminent lawless action," but ordering the University to "take all necessary and appropriate steps, within their available resources, to provide security" for speakers, attendees, "peaceful protesters" and others). Auburn subsequently agreed to pay Padgett's legal fees. Chip Brownlee, University Agrees to Pay \$29K to Dismiss Richard Spencer Lawsuit, Auburn PLAInSman (May 15, 2017, 9:32 AM), http://www.theplainsman.com/article/2017/05/university-agrees-to-pay-29kto-dismiss-richard-spencer-lawsuit. The University's fears did not pan out; the event proceeded with only "confined" skirmishes, involving a few people. See Travis M. Andrews, Federal Judge Stops Auburn from Canceling White Nationalist Richard Spencer Speech. Protests and a Scuffle Greet Him, WASH. POST (Apr. 19, 2017), https://www.washingtonpost.com/news/morning-mix/wp/2017/ 04/19/federal-judge-stops-auburn-from-canceling-white-nationalists-speech-violence-erupts/? $\mathrm{utm} \_$term $=.1 \mathrm{db} 83 \mathrm{~d} 63 \mathrm{a} 11 \mathrm{~b}$ (noting that the original version of the article exaggerated the extent of violence, as it only temporarily involved a few angry people).

48 Joseph Goldstein, After Charlottesville, A.C.L.U. Braces for the Next Alt-Right Case, N.Y. TimES (Oct. 4, 2017), https://www.nytimes.com/2017/10/04/us/aclu-charlottesville-white-supremacists.html.

49 See Timothy J. Heaphy, Hunton \& Wildiams LLP, Final Report: IndePENDENT ReView OF the 2017 PRotest Events in Charlottesville, Virginia 50, 156-57 (2017) https://www.hunton.com/images/content/3/4/v2/34613/final-report-ada-compliant-ready.pdf (explaining that Virginia state law prevents localities, including Charlottesville, from passing laws that would have prohibited demonstrators from carrying firearms).

50 The Hunton \& Williams report includes a recommendation that the State of Virginia amend its laws to allow localities to "protect public safety at large protest events" by restricting certain weapons, to the extent permitted by the Second Amendment. Id. at 175 . 
neutral regulations designed to preserve "the existence of an organized society maintaining public order, without which liberty itself would be lost in the excesses of anarchy." 51

Gregory v. City of Chicago, a case the Supreme Court termed "simple" when decided in 1969, overturned the convictions of comedian and social activist Dick Gregory and his companions. ${ }^{52}$ Gregory led a protest march directed at Chicago's slow progress in desegregating its public schools in which protesters first gathered at City Hall and then marched five miles to the home of Chicago's Mayor Bill Daley, where they intended to remain until Daley fired the Superintendent of Schools. ${ }^{53}$ They were accompanied throughout by a contingent of police officers and an assistant city attorney. ${ }^{54}$ Spectators gathered near the Mayor's home. ${ }^{55}$ The crowd of onlookers "kept increasing, and its language and conduct became rougher and tougher." 56 The police feared that they would be unable to contain "the threatening crowd of onlookers," and ordered Gregory and his group to disperse. ${ }^{57}$ Yes, you read that right - they ordered the original marchers, not the hecklers, to disperse, and charged the members of Gregory's group with disorderly conduct when they refused to leave. 58

The Supreme Court was having none of it, especially in light of a record showing that the marchers "did all in their power to maintain order ... in the face of jeers, insults, and assaults with rocks and eggs." 59 A "peaceful and orderly" march, the Court held, "falls well within the sphere of conduct protected by the First Amendment." 60 Concurring, Justice Black found a fatal flaw in the trial court's failure to instruct the jury to ask whether there was "an imminent threat of violence, or whether the police had made all reasonable efforts to protect the demonstrators," and to instead allow the jury to ignore the surrounding circumstances and the violence committed by those labelled as onlookers. ${ }^{61}$

51 Cox v. Louisiana, 379 U.S. 536, 554 (1965). But see Shuttlesworth v. City of Birmingham, 394 U.S. 147, 150-51 (1969) (holding that an ordinance that gives unlimited discretion to those charged with granting parade permits based on their own assessments of "public welfare, . . . safety, ... [or] good order" violates the First Amendment). 394 U.S. 111, 111, 113 (1969).

Id. at $111-12,116$

Id. at 111 .

Id. at 116 (Black, J., concurring).

Id.

Id.

Id. at $116-17$.

Id. at 117 .

Id. at 112 (majority opinion).

Id. at 122 (Black, J., concurring) (internal quotation marks omitted) (citing City of Chicago v. Gregory, 233 N.E.2d 422, 429 (1968)). 
The subsequent line of cases places a heavy burden on public officials who argue that public safety requires them to shut down a demonstration, especially where the ordinance or its application does not appear to be neutral between those who hold different viewpoints. ${ }^{62}$ When universities "draw the line" at allowing expression that "has the potential to incite violence and/or is a direct threat to members of our community," as an administrator at American University put it in her congressional testimony, ${ }^{63}$ they should reflect carefully on where the risk of violence originates (the speaker or the unintended even if predicable response generated in listeners) and what they mean by a "direct threat" (words protected by the First Amendment that threaten listeners' sensibilities or concrete, physical threats attributable to the speaker based on the speakers' conduct). The risk must be real, proximate, and attributable to the speaker before a speaker engaged in protected speech may be silenced without violating the speaker's constitutional rights.

This brings us back to the problem of how college campuses faced with outside speakers and protesters who are not part of the campus community should balance the sometimes-competing imperatives of free expression and preserving safety for students, faculty, employees, and community members.

A threshold question involves whether outsiders have any right to express themselves on a college campus. The cases discussed above all involved public spaces belonging to the government, and not reserved for dedicated purposes excluding free expression - in First Amendment parlance, public fora. A public forum is a space like a public street or park that from "[ $\mathrm{t}]$ ime out of mind" has been "used for public assembly and debate," where expressive rights are at their zenith. ${ }^{64}$ Yet even in a public forum, speakers are subject to government regulation, including reasonable time, place, and manner regulations. Those may include content-neutral permit-

62 See Madsen v. Women's Health Ctr., Inc., 512 U.S. 753, 790-95 (1994) (Scalia, J., concurring in the judgment in part and dissenting in part) (stating that an injunction constraining one side of an ideological dispute should be reviewed under strict, not intermediate, scrutiny); Sabel v. Stynchcombe, 746 F.2d 728, 730-31 (11th Cir. 1984) (overturning conviction for refusal to disperse where police, citing fear of an impending riot, failed to show a risk of "imminent violence" attributable to "abrasive" May Day demonstrators - the First Amendment is not limited to "speech which is well-mannered and attentive to the preferences of others"); see also McCullen v. Coakley, 134 S. Ct. 2518, 2534-39 (2014) (holding that a 35-foot buffer zone around abortion clinics violates the First Amendment because while content neutral and responsive to a record of violence outside such clinics, it was not narrowly tailored and interfered with those who merely wished to "inform" not to protest).

63 Free Speech 101: The Assault on the First Amendment on College Campuses: Hearing Before the S. Comm. on the Fudiciary, 115th Cong. (June 20, 2017) (testimony of Fanta Aw, Interim Vice President of Campus Life, American University), https://www.judiciary.senate.gov/imo/media/doc/06-20-17\%20Aw $\% 20$ Testimony.pdf.

64 Snyder v. Phelps, 562 U.S. 443, 456 (2011) (quoting Frisby v. Schultz, 487 U.S. 474, 480 (1988)). 
ting schemes, mechanisms that impose buffer zones between opposing demonstrations, and the like. 65

A college campus - even a public one - may or may not constitute a public forum, and different parts of the campus may fall into different categories of fora depending on their history and the ways in which the spaces are used. Outside speakers and demonstrators who are not part of the campus community may not have the same presumptive right to express themselves on the campus as those who are enrolled as students. However, if a campus makes its space available to one of the categories of users set out below, it violates the Speech Clause when it discriminates among potential speakers who are similarly-situated based on the content or viewpoint they wish to share. ${ }^{66}$

Outside speakers arrive at college campuses by several different mechanisms, which may have constitutional significance. Reviewing recent events, I have categorized the ways in which speakers who are not part of the university community arrive on campus. They may:

(1) be invited by the college administration to give a particular lecture, participate in a conference or debate, or in connection with an award, such as an honorary degree;

(2) be invited by a faculty member, perhaps as part of an official program under the auspices of a center or institute, or as a guest speaker in a class;

(3) be invited by a recognized student group in accordance with university rules allowing such groups to invite outsiders to speak;

(4) be invited by individual students, a route that may or may not be formally recognized by the institution;

(5) initiate his or her own use of a space that has been designated as a public forum;

(6) take advantage of alumni status to use a university space or be invited by a person with alumni or other university affiliation if the university rules permit; or

(7) pay to rent a space that the university offers to the public on a commercial basis.

Space, time, and attention are limited. Arguably, consistent with the university's educational and research mission, speakers who receive official invitations because they are deemed likely to enhance the quality or range

65 See id. at 456-57 (describing how Maryland subsequently enacted a law imposing arguably content-neutral restrictions on picketing at funerals).

66 See Widmar v. Vincent, 454 U.S. 263, 277 (1981) (holding that a university that allows student groups to use its facilities may not distinguish among those groups based on content). 
of dialogue on campus, or those invited by members of the campus community who actually want to hear what they have to say, should take priority over those who invite themselves (as Chicago recently stated). The route that brings outside speakers to campus may have constitutional implications that affect their access to the campus podium.

When the university or members of the faculty invite speakers to campus, our initial presumption should be that the invitation is intended to promote the university's educational and/or research goals. To choose which speakers to invite, any person or entity (not just colleges) organizing an event must make content-based inquiries and decisions: Is the speaker an authority worth listening to? Is the speaker's expertise valuable or even relevant to the subject of the forum or debate we want to sponsor? Does the speaker bring value to our audience, and serve the institution's educational and broader goals? If a university is faithful to its mission, it will strive to invite (or at a minimum, not restrict) speakers who represent a range of opinions, if not at every event, at least over the course of the academic year.

On the other hand, even if the First Amendment protects the right to voice worthless ideas we expect to evaporate when challenged in the marketplace, a university has no obligation, and indeed no defensible reason, to make its platforms available to speakers who would undermine the university's essential goals of discovering and disseminating knowledge. Why would a university or faculty member offer a platform to those who deny the scientific method, or attack the premises of analytical thinking, or of verifiable truths?

The controversial speakers in the news this past year were primarily invited by a student group (often with funding from an outside organization for a celebrity speaker) or used policies allowing people to rent or reserve university space for public events - in other words, the university as such did not invite them. If they rented space, they invited themselves. This is the approach white nationalist Richard Spencer (who is at the center of several of the controversies highlighted below) generally uses. ${ }^{67}$ Speakers who use their moments on campus to spew epithets without much more may be upsetting, but do little or nothing to promote the dialogue modelled by Socrates, and thus do not promote the unique mission of higher education or elevate public discourse in a way that might be part of a university's mission. This view suggests that universities might well be justified in reconsidering or tweaking the "open to all comers" stance that allows presen-

67 See, e.g., Anna L. Peterson, I Teach Ethics at the University Where Richard Spencer Spoke, CONVERSATION (Oct. 20, 2017, 12:15 PM), https://theconversation.com/i-teach-ethics-at-theuniversity-where-richard-spencer-spoke-86025 (documenting that Richard Spencer "was not invited by anyone at UF, but he rented a lecture hall . . . as nonuniversity groups do all the time."). 
tations by outsiders with marginal connections to the campus or those who can afford to rent space, especially in light of the apparent risks and high costs imposed on the institution that flow from such events today.

However, as long as the doors to university platforms remain open, speakers should not be denied access for reasons or in ways that violate First Amendment doctrine or norms.

Just as outsiders come to campus in several ways, cancellations fall into several patterns.

First, administrators may get cold feet in light of disruptions and violence elsewhere, and sometimes just in response to objections from other outsiders that the speaker is too controversial. Second, students and even faculty have called on colleges to "disinvite" controversial speakers and, as noted above, have sometimes made it impossible for scheduled events to take place. ${ }^{68}$ But much contemporary attention is focused on the last constellation: real and seeming threats posed by outside agitators and protesters that raise the specter of violence. I distinguish agitators who come with the announced intention of provoking disturbance, and even violence, from protesters who come to assert their own views. Protesters - whether students or outsiders - are exercising First Amendment rights. So are audience members who want to hear the message the speaker aims to deliver. ${ }^{69}$

Let me briefly capture the salient details of what happened in 2017 in Berkeley, Charlottesville, and at the University of Florida's main campus in Gainesville before returning to my doctrinal discussion.

Public attention has been focused on cancelled events since February 2, 2017 when the scheduled appearance of provocateur Milo Yiannopoulos caused a riot at Berkeley, as opposed groups of demonstrators confronted each other, and some demonstrators started fires and hurled Molotov cocktails. ${ }^{70}$ This incident was quickly followed by the drowning out of author

68 See Eliot C. McLaughlin, War on Campus, CNN (May 1, 2017, 12:04 PM), http://www.cnn.com/ 2017/04/20/us/campus-free-speech-trnd/index.html (noting that there have been "more than 300 attempts to disinvite campus speakers since 2000”); see also Abby Jackson, 'Disinvitations' for College Speakers are on the Rise-Here's a List of People Turned Away this Year, BUS. INSIDER (July 28, 2016, 1:09 PM), http://www.businessinsider.com/list-of-disinvited-speakers-at-colleges-2016-7 (listing universities that disinvited controversial speakers in 2015-2016, including Brown University, California State University at Los Angeles, University of California at Berkeley, University of Chicago, George Washington University, Trinity College, Hampshire College, University of Pennsylvania, San Francisco State University, Virginia Tech, and Williams College).

69 See Stanley v. Georgia, 394 U.S. 557, 564 (1969) ("It is now well established that the Constitution protects the right to receive information and ideas."); see also Catherine J. Ross, An Emerging Right for Mature Minors to Receive Information, 2 U. PA. J. CONST. L. 223, 230-31 (1999) (discussing Supreme Court and lower court opinions regarding the right to receive information).

70 See Madison Park \& Kyung Lah, Berkeley Protests of Kiannopoulos Caused \$100,000 in Damage, CNN (Feb. 2, 2017, 8:33 PM), http://www.cnn.com/2017/02/01/us/milo-yiannopoulos-berkeley/ index.html (reporting that individuals protesting a planned appearance by Milo Yiannopoulos 
Charles Murray at Middlebury College and a string of comparable events..$^{71}$ In each of these instances, and others, hecklers exercised a veto over constitutionally protected speech, a veto that violated constitutional norms.

In September 2017, Milo Yiannopoulos purportedly planned a reprise of his February appearance at Berkeley, a week designated Free Speech Week, with lots of right-wing speakers, invited by a conservative student group. ${ }^{72}$ The students withdrew the invitation a few days before the week was supposed to start and complained to the U.S. Department of Justice that the University had been hostile and had placed bureaucratic obstacles in their way. ${ }^{73}$ The students who had originally invited Yiannopoulos claimed they couldn't guarantee the speakers' safety. ${ }^{74}$ The University had in fact rebuffed the mayor's plea that it cancel the event, and it had planned to spend upwards of $\$ 1$ million to ensure everyone's safety. ${ }^{75}$

threw commercial-grade fireworks, rocks, and Molotov cocktails).

71 See Eugene Volokh, Protestors at Middlebury College Shout Down Speaker, Attack Him and a Professor, WASH. POST (Mar. 4, 2017), https://www.washingtonpost.com/news/volokh-conspiracy/wp/2017/03/ 04/protesters-at-middlebury-college-shout-down-speaker-attack-him-and-a-professor/?utm_term= $.0607 \mathrm{c} 2 \mathrm{~b} 06839$ (describing how protestors violently confronted controversial author Charles Murray and a Middlebury College professor); see also Kurtz, supra note 6.

72 See Susan Svrluga, Bannon, Yiannopoulos Plan to Speak at 'Free Speech Week' at UC-Berkeley, WASH. POST (Sept. 13, 2017), https://www.washingtonpost.com/news/grade-point/wp/2017/09/12/ bannon-yiannopoulos-to-speak-at-free-speech-week-at-uc-berkeley/?utm_term=.b38d23d25d7a. Before the event, many speakers, including Charley Murray, Heather MacDonald, and Michael Malice, who reportedly were "invited" said that they had never been invited, or had never planned to come. See, e.g., Chris Quintana, Speaking at Berkeley with Milo Yiannopoulos? It's Newes to Them, GHRON. Higher EdUc. (Sept. 15, 2017), https://www.chronicle.com/article/Speakingat-Berkeley-With-Milo/

241226 (reporting that Charles Murray had never planned to come and "never under any circumstances [would he] appear at an event that included Milo Yiannopoulos" and that Heather MacDonald and Michael Malice would not attend).

73 See Nanette Asimov, Conservative Berkeley Students Ask US Justice Department to Launch Investigation, S.F. CHRON. (Oct. 4, 2017), http://www.sfchronicle.com/education/article/Conservative-Berkeleystudents-ask-US-Justice-12254070.php (reporting that the students cancelled the event because they allegedly feared that they would be the target of a retaliatory police investigation instigated by the university).

74 See Frances Dinkelspiel, Berkeley Patriot Cancels 'Free Speech Week'; Milo Plans a March on Sproul, BERKELEYSIDE (Sept. 23, 2017, 9:32 AM), http://www.berkeleyside.com/2017/09/23/berkeleypatriot-group-cancels-free-speech-week-milos-plans-unknown/\# (reporting concerns that the University could not provide sufficient security).

75 See Rachel Chason, Berkeley's Mayor Asked UC Berkeley to Cancel Milo Miannopoulos Speech. The School Said No, WASH. POST (Aug. 30, 2017), https://www.washingtonpost.com/news/morning$\mathrm{mix} / \mathrm{wp} / 2017 / 08 / 30 /$ berkeleys-mayor-asked-uc-berkeley-to-cancel-milo-yiannopoulos-theuniversity-said-no/?utm_term $=.654543 \mathrm{f6a} 985$ (noting that the University stated it has no "desire to interfere with or cancel their invitations based on the perspectives and beliefs of the speakers"); see also Aaron Hanlon, What Stunts Like Milo Tiannopoulos's 'Free Speech Week' Cost, N.Y. TimES (Sept. 24, 2017), https://www.nytimes.com/2017/09/24/opinion/milo-yiannopoulos-free-speech-week -berkeley.html (detailing how the University of California, Berkeley administration planned to spend one-million dollars on Milo Yiannopoulos's "Free Speech Week"). In the month spanning August 27 to September 27, 2017, the University of California, Berkeley spent nearly four-million 
Yiannopoulos came to Berkeley anyway, where he spoke for fifteen minutes "as a private individual" at Berkeley's famed Sproul Plaza, a public forum that had been the site of the Free Speech Movement in the 1960s. ${ }^{76}$ The University reportedly spent $\$ 800,000$ to ensure safety and order during those fifteen minutes of additional fame for Yiannopoulos. ${ }^{77}$ At Michigan a few weeks later, students again shouted down Charles Murray who persisted in speaking in the face of disruptive protests inside the lecture hall. ${ }^{78}$

Other schools have disinvited speakers including Spencer, citing concerns for public safety. ${ }^{79}$ Still other speakers back out in the face of virulent opposition - for example, at George Washington University, where I teach, a controversial Brazilian politician declined to appear in 2017 after 900 people from around the world signed a letter protesting what they termed his "racist, sexist, homophobic right-wing extremist" views. ${ }^{80}$

Charlottesville seemed to be a game-changer. As the New York Times observed, "Charlottesville changed how universities looked at controversial speakers. It changed how they assessed the literal and figurative cost of free speech. It changed how they secured events with a higher potential for violence."'81

dollars on security for just three high profile speech events, including the Yiannopoulos appearance. See Ashley Wong, UC Berkeley Spent \$4 Million on 'Free Speech' Events Last Year, DAILY CALIFORNIAN (Feb. 4, 2018), http://www.dailycal.org/2018/02/04/uc-berkeley-split-4m-costfree-speech-events-uc-office-president/ (reporting that documents revealed a much higher price tag for security than had previously been disclosed).

76 See Richard Gonzales, Berkeley's Fight for Free Speech Fired Up Student Protest Movement, NPR (Oct. 5, 2014, 7:57 AM), https://www.npr.org/2014/10/05/353849567/when-political-speech-wasbanned-at-berkeley; Jill Tucker et al., Yiannopoulos Visits Sproul for 15 Minutes; UC Berkeley Spends $\$ 800,000$, SFGATE (Sept. 24, 2017), https://www.sfgate.com/bayarea/article/Yiannopoulosvisits-Sproul-for-15-minutes-UC-12225043.php.

77 See Tucker, supra note 76 (detailing how Milo Yiannopoulos "prayed, signed autographs and took selfies for about 15 minutes").

78 Jesse Arm, We Brought Charles Murray to Campus. Guess What Happened, N.Y. Times (Oct. 12, 2017), https://www.nytimes.com/2017/10/12/opinion/charles-murray-michigan-speech.html (describing how protesters rendered the lecture "inaudible"); Morgan Showen, Students Attempt to Shut Dowen Speech by Controversial Social Scientist Charles Murray, Mich. DAILY, (Oct. 11, 2017), https://www.michigandaily.com/section/government/students-attempt-shut-down-speechcontroversial-social-scientist-charles-murray (detailing how protesters halted the speech by playing music, shutting off lights, shouting, delivering their own comments from the podium, and chanting before marching out, at which point Murray was able to take questions from the remaining students).

79 Holly Yan, White Supremacist Richard Spencer Denied at University of Florida, CNN (Aug. 17, 2017, 1:41 AM), https://www.cnn.com/2017/08/16/us/richard-spencer-denied-at-university-of-florida-trnd /index.html.

80 Open Letter to George Washington University Opposing the Platforming of Jair Bolsonaro, STOP BOLSONARO (Oct. 4, 2017), https://stopbolsonaro.wordpress.com/2017/10/04/open-letter-to-gwu/; see Justine Coleman, Right-Wing Brazilian Politician Cancels Elliott School Event, GW HATcheT (Oct. 13, 2017, 12:04 AM), https://www.gwhatchet.com/2017/10/13/right-wing-brazilian-politiciancancels-elliott-school-event/ (noting that Bolsonaro is reported to have cancelled the event in light of GW scholars' and journalists' planned dialogue).

81 Audra D. S. Burch, Campuses Brace for Angry Words, N.Y. Times, Jan. 18, 2018, at A18. 
But Charlottesville muddies the waters. The Charlottesville march and counter-demonstration were not university events. They did not take place on the university campus. ${ }^{82}$ Nor did the vehicular homicide. The white nationalist "Unite the Right" rally of August 11-12, 2017 took place in the City of Charlottesville, under a permit granted by the city, initially as a matter of course and then under court order, ${ }^{83}$ as did the counterdemonstration by permit holders located in another park. The University, the public parks, and downtown Charlottesville are all in close proximity.

Context matters. Three protests organized by white nationalists took place in Charlottesville within the span of a few months in 2017, none of them scheduled to take place on the university campus. ${ }^{84}$ The first and last of these events (the last being the infamous incidents that took place in August 2017) were convened by white nationalist Richard Spencer and his allies. ${ }^{85}$

Richard Spencer led the white nationalists when they returned to Charlottesville on August 11-12 for what they called the "Unite the Right" event (the "Charlottesville incidents"). ${ }^{86}$ The white nationalists, some of

82 The events of August 11-12 are widely misrepresented even in venues that should know better. See, e.g., Nell Gluckman, Faculty Members Organize to Fight 'Fascist' Interlopers on Campuses, CHRON. HighER EDUC., Sept. 15, 2017, at A28 (discussing the Campus Anti-Fascist Network that has grown from 40 to over 400 members "[s] ince a white-supremacist rally in Charlottesville, Va. that started on the University of Virginia campus turned deadly in August"); Sophie Quinton, Will Charlottessille Hurt the Movement to Strengthen Free Speech on College Campuses?, GovernING (Aug. 24, 2017), http://www. governing.com/topics/education/sl-universities-colleges-free-speech-charlottesville.html (describing "[t]he sight of white supremacists marching through the heart of the University of Virginia").

83 See Bryan McKenzie, Fudge Allowes Unite the Right Rally to Stay in Emancipation Park, Daily Progress (Aug. 11, 2017), http://www.dailyprogress.com/news/local/judge-allows-unite-the-right-rally-tostay-in-emancipation/article_9965d0be-7ee6-11e7-ab0e-f342e0cf9488.html (reporting that a federal judge granted an injunction allowing a far-right rally to be held in Emancipation Park); see also supra note 47.

84 See Laura Vozzella, White Nationalist Richard Spencer Leads Torch-Bearing Protesters Defending Lee Statue, WASH. POST (May 14, 2017), https://www.washingtonpost.com/local/virginia-politics/altrights-richard-spencer-leads-torch-bearing-protesters-defending-lee-statue/2017/05/14/

766aaa56-38ac-11e7-9e48-c4f199710b69_story.html?utm_term=.f84a55112941 (describing two white nationalist protests in the city of Charlottesville); see also HEAPHY, supra note 49, at 2-4, 3140 (describing a permitted rally in Charlottesville by a Ku Klux Klan group from North Carolina, including preparatory measures taken by authorities).

85 See Hawes Spencer \& Sheryl Gay Stolberg, White Nationalists March on University of Virginia, N.Y. TiMES (Aug. 11, 2017), https://www.nytimes.com/2017/08/11/us/white-nationalists-rallycharlottesville-virginia.html (detailing how Jason Kessler organized a "Unite the Right" Rally in Charlottesville, Virginia).

86 See Kurt Chirbas et al., White Nationalist Richard Spencer Leads Torch-Carrying Crown in Charlottsville, NBC (Oct. 8, 2017, 8:05 PM), https://www.nbcnews.com/news/us-news/white-nationalistrichard-spencer-leads-torch-carrying-crowd-charlottesville-n808766 (describing how Richard B. Spencer led other white nationalists in a march near the University of Virginia); see also Richard Fausset \& Alan Feuer, Far-Right Groups Surge Into National View in Charlottesville, N.Y. Times (Aug. 13, 2017), https://www.nytimes.com/2017/08/13/us/far-right-groups-blaze-into-national-viewin-charlottesville.html (describing the marches of white nationalists). 
whom were armed, marched with lighted torches ${ }^{87}$ (now illegal on the campus) $)^{88}$ chanting racist slogans, including "Jews will not replace us." 89 (Accounts of intimidation, confrontation, and anti-Semitism throughout the city during those few days are beyond the scope of this commentary. ${ }^{90}$ ) Community leaders on-campus and off-campus, organized as Congregate Charlottesville, ${ }^{91}$ prepared both counter-protests and competing events, ${ }^{92}$ while university administrators urged the campus community to stay home. ${ }^{93}$ Antifa and other groups arrived. ${ }^{94}$

For our purposes of thinking about speech and safety on college campuses, what matters is that Unite the Right arrived the night before their permitted activity was set to begin and entered the campus without permission or permits. On Friday evening, August 11, Spencer and more than 300 torch-bearing supporters headed to the iconic Rotunda and the statue of Thomas Jefferson on the university campus, regarded by many at the University as "sacred ground." 95 As I observed them when speaking at the

87 See Joe Heim, Recounting a Day of Rage, Hate, Violence, and Death, WASH. Post (Aug. 14, 2017), https://www.washingtonpost.com/graphics/2017/local/charlottesville-timeline/?utm_term=. $78116 \mathrm{cbb} 3549$ (detailing that the white nationalists were "heavily armed").

88 See Bill Morlin, Fiery Torch Demonstrations Now Illegal on Virginia Campus, S. POVERTy L. CTR. (Sept. 18, 2017), https://www.splcenter.org/hatewatch/2017/09/18/fiery-torch-demonstrations-nowillegal-virginia-campus (explaining how the University of Virginia's Board of Visitors unanimously voted in favor of banning "open flames, explosives and weapons" from an outdoor area on its campus).

89 Yair Rosenberg, 'Gewes Will Not Replace Us': Why White Supremacists Go After Fewes, Wash. Post (Aug. 14, 2017), https://www.washingtonpost.com/news/acts-of-faith/wp/2017/08/14/jews-will-notreplace-us-why-white-supremacists-go-after-jews/.

$90 \quad$ See generally Emma Green, Why the Charlottessille Marchers Were Obsessed with Fews, ATLANTIC (Aug. 15, 2017), http://www.theatlantic.com/politics/archive/2017/08/nazis-racism-charlottesville/ 536928/ (describing the "Unite the Right" rally as being not only "suffused with anti-black racism, but also with anti-Semitism); Alan Zimmerman, In Charlottesville, the Local Ferwish Community Presses On, REFORMJUdAISM.ORG (Aug. 14, 2017), https://reformjudaism.org/print/233696 (describing men armed with semi-automatic rifles across the street from the synagogue, marching and chanting "Seig Heil," as the Rabbi urged congregants to leave by the back door for safety).

91 See Taylor Gleason, Congregate Charlottesville Plans to Attend Unite the Right Rally, NBC29 (July 27, 2017), http://www.nbc29.com/story/35989996/congregate-charlottesville-plans-to-attend-unitethe-right-rally (noting that Congregate Charlottesville called on thousands of faith leaders across America to join in "prayerful protest" against the "Unite the Right" rally).

92 Id.

93 See Peta DeLuca, UVA President Wants UVA Community to Avoid Unite the Right, NBC29 (Aug. 5, 2017), http://www.nbc29.com/story/36064974/uva-president-wants-uva-community-to-avoidunite-the-right (describing how the University of Virginia president called on students and members of the community to avoid the "Unite the Right" rally and violent confrontation); see also Julia Schmalz, What Lies Ahead in the Campus-Speech Wars?, Chron. Higher EdUc. (Sept. 13, 2017), https://www.chronicle.com/article/What-Lies-Ahead-in-the/241 160 (advocating that colleges recommend that community members participate in other events or respond with "more convincing" speech).

94 HEAPHY, supra note 49 , at 51.

95 Dean Seal, Sullivan: Protest Desecrated Sacred Ground: President Sends Different Messages to School Community and Alumi, DAILY Progress, Sept. 14, 2017, at A1. 
University of Virginia a few weeks later, these iconic symbols of the University of Virginia are easily accessible, just off a public street. There is a gate that could have been closed but wasn't. But the brief excursion to the University was a side event. A roughly 200-page analysis of the Charlottesville incidents devotes no more than five pages to the University, including discussion of the City's efforts to coordinate with university officials and campus police in the weeks leading up to the August events. ${ }^{96}$

The day after the Unite the Right rally, a self-identified Nazi who had come to Charlottesville to participate in Unite the Right weaponized his car - killing one counter-protester and injuring more than thirty-five people. ${ }^{97}$ This violence within the city is appropriately on everyone's mind when we think of the Charlottesville incidents, and university administrators elsewhere point to this violence as a reason to bar provocative speakers from campuses. But at best the death and injury in Charlottesville underscore the difficulty of drawing bright lines between town and gown when public safety is at issue. And safety is a more than legitimate concern: the three years ending in 2017 witnessed three of the five highest death counts in the United States at the hands of extremists since 1970; in 2017 white supremacists committed the largest number of extremist-related killings, according to the Anti-Defamation League. ${ }^{98}$

The car attack that killed Heather Heyer and injured scores of others was hardly the only break down of public safety during those few days in Charlottesville. A lot went wrong, indeed the breakdown of order was "disastrous" according to outside consultants: the buffers between opposing groups of demonstrators proved permeable and law enforcement officers failed to intervene as melees broke out. ${ }^{99}$ Charlottesville should not be taken as an example of a university event gone awry or used to justify restrict-

96 HEAPHY, supra note 49, at 40, 102-03, 105, 158.

97 See Paul Duggan, Charge Upgraded to First-Degree Murder for Driver Accused of Ramming Charlottesville Crowd, WASH. POST (Dec. 14, 2017), https://www.washingtonpost.com/local/crime/driveraccused-of-plowing-into-charlottesville-crowd-killing-heather-heyer-due-in-court/2017/12/13/ 6cbb4ce8-e029-11e7-89e8-edec16379010_story.html?utm_term=.ca3d28980d73 (reporting that a neo-Nazi was charged with first-degree murder after killing a woman with his car).

98 See Anti-Defamation League, Murder And Extremism in the United States in 2017 (2017), https://www.adl.org/education/resources/reports/murder-and-extremism-in-the-unitedstates-in-2017 (noting that deaths are the "tip of a pyramid" as many injuries also result, with longterm consequences for victims and others).

99 See Nick Visser, Charlottesville Police Chief Resigns After Report Slams Response to White Supremacists, HUFFPOST (Dec. 18, 2017), https://www.huffingtonpost.com/entry/charlottesville-police-chiefal-thomas_us_5a38481fe4b0860bf4aa8719 (describing how "violent confrontations could have been but were not prevented by police" (quoting Timothy Heaphy, chief author of HEAPHY, supra note 49)); see also Jaweed Kaleem et al., Charlottesville Police Face Critics as a Tense City Tries to Regroup from Deadly Weekend, L.A. Times (Aug. 13, 2017), http://www.latimes.com/nation/la-nacharlottesville-rally-20170813-story.html (noting that Charlottesville police "seemed caught off guard or, in other cases, seemed to ignore violence the city had vowed to prevent"). 
ing access to college campuses, even though it provides lessons on the dangers of inadequate planning and the need for measures to ensure physical safety when confronted with demonstrators who have announced their intent to provoke and disrupt.

Spencer also invited himself to speak at the University of Florida, under a policy in which the school makes lecture spaces available for rent. ${ }^{100}$ In initially denying Spencer's request to rent space for an appearance on September 12, 2017, the University's President pointed to the "likelihood of violence and potential injury - not the words or ideas" Spencer espoused. ${ }^{101}$ He cited explicit online threats after Charlottesville: "The Next Battlefield is in Florida."102 At the same time the president underscored that he found Spencer's "racist rhetoric ... repugnant and counter to everything the university and this nation stands for." 103

Fearing that it would lose a threatened lawsuit as the Charlottesville incidents receded in time, the University relented and agreed to rent space to Spencer. 104 The President of the University shared his own "shock" at learning that the law requires the University to permit Spencer to voice his "racist views on our campus." $105 \mathrm{He}$ urged members of the campus community to shun Spencer and his event, denying Spencer and his followers the notoriety they seek, and to speak up against hate, while supporting each other and participating in scheduled alternative events that would promote

100 See Katelyn Newberg, Richard Spencer to Speak at UF in Two Weeks, AluIGator (Oct. 5, 2017), http://www.alligator.org/news/article_9b778b7e-aald-1 1e7-91ab-57af07deb281.html (detailing how Richard Spencer, president of The National Policy Institute, rented a space at University of Florida for his speech).

101 Press Release, Univ. of Fla., UF Denies Request for Speaking Event-Message From President Fuchs (Aug. 16, 2017), http://statements.ufl.edu/statements/2017/08/uf-denies-request-forspeaking-event---message-from-president-fuchs.html.

102 Id

103 Id.

104 See Press Release, Univ. of Fla., Personal Message from President Fuchs (Oct. 10, 2017), http://statements.ufl.edu/statements/2017/10/personal-message-from-president-fuchs.html (explaining that while the University did not invite Richard Spencer to speak, it "is required by law to allow Mr. Spencer to speak his racist views on our campus"); Jeremy Bauer-Wolf, Lessons From Spencer's Florida Speech, INSIDE Higher ED (Oct. 23, 2017), https://www.insidehighered.com/ news/2017/10/23/nine-lessons-learned-after-richard-spencers-talk-university-florida (reporting that public institutions "covered by the First Amendment must accommodate speakers"). In the wake of Charlottesville several other colleges also retracted outstanding invitations to Spencer, who threatened or brought legal action. Those institutions had some justification in light of inflammatory online postings like "Today Charlottesville Tomorrow Texas A\&M" (where Spencer had previously spoken in 2016). Sarah Larimer, University of Florida Denies White Nationalist Event Request, Citing Safety Concerns, WASH. POST (Aug. 16, 2017), https://www.washingtonpost.com/ news/grade-point/wp/2017/08/16/university-of-florida-denies-white-nationalist-event-requestciting-serious-concerns-for-safety/?utm_term=.122c6a8f54f2 (discussing developments at Texas A\&M); see also Catherine J. Ross, supra note 14, at 765 (detailing Spencer's 2016 Texas A\&M appearance and the University's response).

105 Press Release, Univ. of Fla., supra note 101. 
"our shared humanity."106 The stark message condemning Spencer's viewpoint did not violate the burden the Speech Clause places on the state to remain neutral among messages, because a college is an educational institution which by its very nature delivers the state's preferred messages to students and others; doing so is an essential part of its mission just as much as promoting an atmosphere that fosters intellectual diversity.

From that point on, Florida provides a roadmap of how to handle such potentially inflammatory situations and stands in stark contrast to the criticisms of how law enforcement agencies and university officials failed to craft a meaningful strategy for responding to the disorder that enveloped Charlottesville in August. ${ }^{107}$ Florida allocated an estimated half a million dollars for security 108 even though there was no "specific heightened threat" by the time Spencer arrived on October 19.109 It sent a team to consult with officials at Berkeley, to learn from how Berkeley handled and marginalized Yiannopoulos's September appearance at Sproul Plaza. ${ }^{110}$ Anticipating rallies surrounding Spencer's appearance, the Governor of Florida declared a state of "potential emergency" the night before Spencer spoke, which facilitated cooperation among various law enforcement agencies and made specialized equipment available to local law enforcement. ${ }^{111}$

Perhaps most important, having concluded that content-neutral application of its policy providing public access to university facilities required it to open its space to Spencer, Florida rented him a space that was some distance from the core campus, was not easily accessible, and was easily contained by law enforcement officials. ${ }^{112}$ Because the weaponizing of vehicles

$106 I d$.

107 HEAPHY, supra note 49, at 40, 102, 105, 158.

108 See Alex Harris, UF to Pay \$500k in Security Costs for Richard Spencer Speech, Miami HeraLd (Oct. 5, 2017, 6:56 PM), http://www.miamiherald.com/news/local/education/article177311986.html (stating that it cost more than $\$ 500,000$ to host white nationalist Richard Spencer).

109 Florida Governor Defends Emergency Before Far-Right Speech, BBC (Oct. 17, 2017), http://www.bbc.com/ news/world-us-canada-41654975.

110 See Alicia Kim, University of Florida Drew Inspiration from UC Berkeley's Handling of 'Free Speech Week' for Richard Spencer Event Security, DAILY CALIFORNIAN (Oct. 24, 2017), http://www.dailycal.org/ 2017/10/22/university-florida-drew-inspiration-uc-berkeleys-handling-free-speech-week-richardspencer-event-security/ (describing how representatives of the University of Florida visited UCBerkeley to observe and learn crowd-control tactics).

111 Lori Rozsa \& Susan Svrluga, Florida Governor Declares State of Emergency in Advance of Richard Spencer Event, WASH. POST (Oct. 16, 2017), https://www.washingtonpost.com/news/grade-point/wp/ 2017/10/16/florida-governor-declares-state-of-emergency-in-advance-of-richard-spencer-event/? utm_term=.68aebd419e38.

112 See Lori Rozsa \& Susan Svrluga, A White Nationalist is Coming to Campus. Florida Prepares as Though for a Disaster., WASH. POST (Oct. 17, 2017), https://www.washingtonpost.com/news/grade-point/wp/2017/ 10/17/a-white-nationalist-is-coming-to-campus-florida-prepares-as-though-for-a-disaster/?utm_term= .fd8297c73d7f (describing how individuals who desire to protest or attend Spencer's speech will have to walk a significant distance because Spencer's event "will be corralled into a corner"). 
was clearly a risk, the University closed off vehicular access to the area surrounding Spencer's lecture except for law enforcement personnel. ${ }^{113}$ The event was marginalized and secured. Because anxieties ran high, the University allowed both students and employees to choose whether or not they wanted to be on campus, with no penalties for absence. ${ }^{114}$

Spencer's talk was a private event on the campus. Spencer controlled all the remaining arrangements. He decided who would receive the tickets required for admission to the lecture hall. ${ }^{115}$ Spencer may have been more fearful of confronting those who didn't agree with him than members of the university community were of being exposed to him. But he didn't get his algorithm right: protesters outnumbered supporters inside the lecture hall. The protesters drowned Spencer out with shouts of "Not in our town! Not in our state! We don't want your Nazi hate!" but the event proceeded. ${ }^{116}$ Outside, hundreds more demonstrated against Spencer and his message, while hundreds of police officers were on hand to ensure order, largely successfully. ${ }^{117}$

Even with everything Florida's President Kent Fuchs did right, and the model Florida provides for preserving speech and safety when strangers storm the gates, Fuchs worries that some students "believed I was complicit in [Spencer's] appearance."118 All of these issues - of preserving vibrant discourse, protecting physical safety, respecting the dignity of members of the campus community, and allocating scarce resources (platforms as well as financial resources) — will likely continue to challenge universities moving forward.

$113 I d$.

114 See Joe Heim et al., 'Go Home, Spencer!' Protesters Disrupt White Nationalist's Speech at the University of Florida, WASH. POST (Oct. 19, 2017), https://www.washingtonpost.com/news/grade-point/ $\mathrm{wp} / 2017 / 10 / 18 /$ uf/?utm_term=.ff56ec42dfaf (noting that the university administration told "professors to be sensitive to students who might not feel safe" and announced that "class attendance was optional for most students").

115 See Meryl Kornfield, Ticket Distribution Days Announced for Spencer Event, ALLIGATOR (Oct. 13, 2017), http://www.alligator.org/news/article_05413424-b068-11e7-ad68-87343ef193f9.html (stating that the National Policy Institute will give tickets "to both supporters and people who want to learn more about the ideas Spencer will discuss").

116 Associated Press, Protesters Drown Out Richard Spencer at University of Florida, N.Y. TIMES (Oct. 19, 2017), https://www.nytimes.com/2017/10/19/us/richard-spencer-florida.html.

$117 I d$. One serious incident related to Spencer's appearance occurred just off campus when three of Spencer's disciples from Texas confronted a group of anti-Spencer demonstrators, chanting "Heil Hitler," leading to a scuffle in which a protester hit the pro-Spencer group's car with a stick, upon which one of the Texans fired a handgun. No one was injured. Alan Blinder, A Roadshow of Hate: Supremacist Rallies Fueled by Travelers From Afar, N.Y. Times (Oct. 28, 2017), https://www. nytimes.com/2017/10/28/us/white-supremacists-rallies.html (underscoring how difficult it is to police rallies filled with outsiders whose presence is facilitated by social media, who are unknown to local law enforcement and are trying to stay under the radar); Deborah Strange, Three Charged in Shooting After Spencer Talk, GaINSEVILLE.COM (Oct. 20, 2017, 4:06 PM), http://www. gainesville.com/news/20171020/three-charged-in-shooting-after-spencer-talk (describing how supporters of white nationalist Richard Spencer were arrested in connection with a shooting).

Burch, supra note 81, at A18. 


\section{STRANGers AT THE Gate: What Gan Universities Do?}

What can colleges do consistent with the First Amendment? What should they do?

\section{A. Preserve Safety}

Universities - and communities like Charlottesville - must keep students, faculty, and staff physically safe. That does not mean emotionally safe - physically safe.

Permission to demonstrate or speak may not be denied absent strong evidence of a risk of violence on the part of the speakers without violating the speaker's First Amendment rights. "Speakers" here includes both the scheduled event and any counter demonstrations. The risk must be attributable to the speakers based on their proclaimed goal of engaging in or provoking others to violence or their incitement of their supporters to illegal actions.

To find out what speakers intend, college administrators should interact with representatives of the off-campus community, and monitor publicly available social media sites that contain clues or overt statements about what the organizers and their followers intend to do. Express threats communicated in social media should be taken seriously.

Careful planning and devoting resources to safety can help to contain potentially explosive situations, as Florida demonstrated. The Constitution does not require self-destruction. To that end, policies like separating opposing groups of demonstrators are not only permissible, but recommended. So too, if events spiral out of control, protesters may be ordered to disperse, but only where the facts warrant such an order. The period just before and just after scheduled events also requires attention and the presence of law enforcement.

However, we need to hold colleges to a strict standard on both safety and free speech. As the Court underscored when it protected the expressive rights of secondary school students protesting the Vietnam War: "undifferentiated fear or apprehension of disturbance is not enough to overcome the right to freedom of expression."119 Free speech doctrine warns that it should not become too easy to deny permission to speak or demonstrate or to break up a demonstration in mid-course. A serious concern exists that some universities will restrict who can invite speakers to campus, close off spaces to the public, and short circuit events that are constitutionally protected. 
Many colleges are reportedly reexamining their policies about outside speakers. For example, responding to Spencer's repeated approaches, Texas A\&M changed its access policy. It no longer allows outsiders who lack any campus affiliation to rent campus facilities. Moving forward, outside speakers must be sponsored by a "recognized" student organization even if they are asked to pay rent for the space they are using. ${ }^{120}$ Some spaces at Texas A\&M remain public fora, "where speakers can share their view points without approval" but also without the risk that observers will believe that the university or members of the campus community endorse the speaker's views. ${ }^{121}$ Other campuses are considering or making similar changes. They can do that, so long as they don't discriminate based on the content or viewpoint of an event. A risk exists, however, that closing off access to outside speakers will restrict the range of views voiced on campus. ${ }^{122}$

\section{B. Distinguish Conduct from Speech}

Conduct that is subject to regulation without violating speech rights can and should be disciplined when it interferes with the speech rights of otherslike shouting and disruption that prevents an event or speech or blocking people from entering a lecture hall. We should watch to see how Chicago applies its new disciplinary standards and see what lessons can be learned. ${ }^{123}$

\section{Distinguish Initial Invitations from Disinvites}

No one has a right to be invited to speak, but once a speaker has been invited, the heckler's veto principle comes into play. There are legal (and moral) distinctions among the responses listed below, all permissible under the First Amendment, and preventing a speaker from being heard, which is the classic heckler's veto, impermissible under our Constitution.

120 Texas AEM Tightens Requirements for Speakers on its Campus, EAGLE (Mar. 22, 2017), http://www. theeagle.com/news/a_m/texas-a-m-tightens-requirements-for-speakers-on-its-campus/article_19c2 7dc2-0f2d-11e7-ad4d-9796519e96e2.html; see Sara Ganim, Texas A $\Xi M$ University Changes Campus Speaker Policy Over Richard Spencer Visit, GNN (Mar. 21, 2017, 4:49 PM), http://www.cnn.com/ 2017/03/21/us/richard-spencer-texas-am-policy/index.html (reporting that moving forward all external speakers must be sponsored by recognized on-campus organizations).

121 Texas A $\mathcal{E}^{2}$ Tightens Requirements for Speakers on its Campus, supra note 120; see Ganim, supra note 120 (describing how speakers can still "gather to espouse their views" because there are still common areas of campuses outside of building facilities which could be considered open public space).

122 See Free Speech 101: The Assault on the First Amendment on College Campuses: Hearing Before the S. Comm. on the Fudiciary, 115th Cong. (2017) (statement of Zachary Wood, the African-American President of Uncomfortable Learning at Williams College), https://www.judiciary.senate.gov/imo/media/ doc/06-20-17\%20Wood\%20Testimony.pdf (testifying about the obstacles to bringing controversial speakers to campus, and a decision by Williams' president to disinvite a speaker the group invited because of his "inflammatory comments about race"). 
People who don't like what the invited speaker is likely to say have a number of options that are consistent with First Amendment principles. These include:

(1) ignore the speaker - stay away (Many schools urge students and faculty to ignore the provocative speaker, but such advice is - in turn - often ignored.);

(2) hold or attend a counter event;

(3) protest peacefully outside the event but do not block those who want to attend;

(4) attend but don't disrupt - signs or t-shirts are okay, as is asking hard questions that challenge the speaker;

(5) condemn noxious views on behalf of the community and reassure the targets of noxious speech (e.g., speech that is racist, antiSemitic, hostile to LGBTs or immigrants) that their peers respect and value them, and will strive to protect them. Where disparaging speech is aimed at individuals or groups the onus should not be on the targets but on all of us.

\section{Promote a Better Understanding of Speech Rights and Responsibilities}

We should not be surprised that by many accounts students arrive at college with little understanding of the strong medicine that is the stuff of speech rights. As I demonstrate in Lessons in Censorship, instead of modeling freedom, public elementary and secondary schools in every part of the country systematically fail to recognize or respect students' First Amendment rights and violate those rights by silencing and punishing speech the Constitution protects. In the process, educators fail to transmit an understanding of why we have free speech and of how to exercise it. And they give students misleading and inaccurate messages - including the message that you can or should expect to be protected from words and ideas that offend you. ${ }^{124}$

Freshman orientation should include remedial education about the speech rights of others, even as many colleges currently promote important

124 See generally Catherine J. Ross, Lessons in Censorship: How SchOOLS AND COURTS SUbVERT STUDENTS' First AMENDMENT Rights (2015), cited in JEFFREy HERBST, ADDRESSING THE REAL CRISIS OF FREE EXPRESSION ON GAMPUS 3 (NEWSEUM 2017) (detailing how "elementary and secondary schools must educate students on the First Amendment" so that they will arrive in college understanding what freedom of expression means and its relevance for those "who want to change society" including minorities and those who feel alienated); Catherine J. Ross, College Is Too Late to Teach Free Speech, Chron. Higher Educ.: Chron. Rev., (Feb. 12, 2017), https://www.chronicle.com/article/College-Is-Too-Late-to-Teach/239147 (describing how public schools "censor and punish controversial constitutionally protected speech of all sorts"). 
dignitary values including empathy and mutual respect. For example, Purdue University, which recently adopted the University of Chicago's policies on speech rights, also introduced lessons on freedom of expression as part of freshman orientation. ${ }^{125}$ As more colleges strive to educate students about freedom of expression and why it matters, modules that can easily be adapted for use elsewhere should become widely available.

\section{E. Send Positive Messages to the University Community}

When the Constitution requires a college to provide a platform to speakers or demonstrators whose message administrators find noxioussuch as the message of white supremacists or those who condemn LGBTs - officials should distance the institution from the speaker and the message. The President of the University of Florida was unwavering in condemning Spencer's views, tweeting corrections to Spencer's claim that the President "stood behind him" and labelling Spencer's message "vile and despicable." 126 That sort of clear counter message reassures the targets of racist speech that they are not alone and offers a powerful corrective: the more and better speech the First Amendment contemplates. On the day Spencer spoke, Florida's bell tower filled the campus with the civil rights anthem "Lift Every Voice and Sing."127 These were more than gesturesthey kept the campus united and comfortable during a very difficult time.

Avoidance won't work. President Sullivan at the University of Virginia was widely criticized for failing to call Spencer out as a racist. ${ }^{128}$

Advocates of preserving freedom of expression on college campuses will likely need to confront several emerging challenges in the coming months and years. In particular, we need to respond to the serious risks of violence, including gun violence which has until now largely been separated from campus protests. Open carry laws, many of which expressly apply to college campuses (for example, in Texas), ${ }^{129}$ have the potential to make cam-

125 Sarah Brown, The Free Speech Stronghold, CHRON. Higher EDUC., Sept 22, 2017, at A12 (noting that Purdue is believed to be the first college to include an orientation program "focused solely on the First Amendment" as part of positioning itself as an "exemplar of institutional support for open and robust debate").

126 Bauer-Wolf, supra note 104.

127 Id.

$128 \quad I d$.

129 See S.B. 11, 85th Leg., 84th Reg. Sess. (Tx. 2015) ("A license holder may carry a concealed handgun on or about the license holder's person while the license holder is on the campus of an institution of higher education or private or independent institution of higher education in this state.”). 
pus confrontations not only more violent but deadlier. Statutory changes and legal challenges seem imperative. We also need to consider how to mitigate or entirely relieve campuses of the enormous financial burden of protecting campus safety while respecting freedom of expression, as public colleges are required to do. Current legal doctrine prevents colleges from passing the cost of the extraordinary precautions controversial speakers require on to the speakers and their sponsors. ${ }^{130}$ Public safety is not easily assigned to the town or gown because the perimeter is always permeable in both directions. It would make sense for states to adopt legislation transferring such costs from educational institutions to state or local law enforcement- especially given the risks that events on campus will spill over into community spaces and vice versa (though I concede that the prospect of such legal changes in the current climate is remote).

As a pragmatic matter, in the contemporary world, we may have to triangulate speech rights, equality and dignitary rights, and Second Amendment rights. The Woodward Report got it right: whether as a matter of constitutional law or (at private universities) in light of the university's distinctive mission, freedom of expression may never permissibly be sacrificed to other principles no matter how fundamental those other principles may be. There is no more important guarantee for liberty.

Freedom of speech should not be a matter of partisan politics - it is neither a liberal nor a conservative cause, although in the 1960s it seemed that people on the left were the primary proponents of free expression, while today it often seems the tables have turned. Some people seem to have forgotten that the exercise of First Amendment rights has been essential to every form of social protest and reform - from expanding the right to vote to women and racial minorities to integrating public facilities to the battle against police brutality today. Freedom of expression is, quite simply, the engine oil of democracy.

130 See Forsyth Cty. v. Nationalist Movement, 505 U.S. 123, 137 (1992) (holding that an ordinance which "ties the amount of the fee to the content of the speech and lacks adequate procedural safeguards" is unconstitutional); Complaint at 1-2, Padgett v. Pinto, No. 1:18cv00013 (S.D. Ohio Jan. 8, 2018) (challenging a security fee imposed on "controversial" speakers, such as Richard Spencer, in addition to a rental fee for a room at the University of Cincinnati). 
